\title{
IRON \& STEEL INDUSTRY IN JAPAN 1954
}

\author{
Naonori Sumino
}

President, The Iron and Steel Institute of Japan

The iron and steel industry of Japan almost completed during 1954 its equipment modernization program which greatly contributed to the production of iron and steel. Not only was production increased, but the quality of products was improved and manufacturing costs much reduced.

From the view point of raw materials, the amount of imported iron ore was 5, 005, 000 tons and domestic ore, including iron sands and pyrite cinders, was 2,830,447 tons. The amount of imported coking coal was 3,072,000 tons.

The production of iron and steel during 1954 as compared with that in 1953 showed an increase of $2 \%$ in pig iron, $1 \%$ for steel ingot and $3 \%$ for hot rolled products, as shown in the following table, and set a new peak for the annual total in Japan.

\begin{tabular}{c|c|c|c}
\multicolumn{2}{|c}{ Unit : 1,000 tons } \\
\hline & Pis Iron & Steel Ingots & Hot Rolled Products \\
\hline 1953 & 4,518 & 7,622 & 5,182 \\
1954 & 4,608 & 7,740 & 5,357 \\
\hline
\end{tabular}

In the field of equipment, the following plants were established :

"Sintering plant" of Nakayama Steel Works, Ltd.

"100-ton open hearth furnaces" (3 units) at Chiba Works, Kawasaki Iron and Steel Corporation Ltd.

"Blooming and slabbing mill" at Kure Works, Nichia Steel Works, Ltd.

"Blooming and slabbing mill" at Chiba Works, Kawasaki Iron and Steel Corporation, Ltd.

"Plate mill" at Tsurumi Works, Nippon Steel Tube Co., Ltd.

"Tandem cold mill" at Yawata Works, Yawata Iron \& Steel Co., Ltd.

"Cold strip mill" at Kure Works, Yodogawa Steel Works, Ltd.

"Cold strip mill" at Osaka Works, Nippon Teppan Co., Ltd.

"Fretz-Moon continuous tube mill" at Kawasaki Works, Nippon Steel Tube Co., Ltd.

"Electrolytic tinning line" at Yawata Works, Yawata Iron \& Steel Co., Ltd.

"Continuous rod mill” at Hikari Works, Yawata Iron \& Steel Co., Ltd.

Technical efforts were made mostly to increase productivity, to imnprove quality and to lower costs. In the field of manufacturing pig iron, more weight was put on ore beneficiation with the result that the ratio of using sintered ore increased to over $40 \%$. In consideration of the coke-ratio in order to see the operating conditions of blast fu- 
rnaces, the national average was 0.793 in January, 1954, but it gradually decreased to 0.706 in October.

In the field of steel manufacturing, the use of producer gas continued to decrease as in the previous year and heavy oil took its place as fuel for open hearth furnaces. The pig ratio was about $50 \%$, out of which $40 \%$ was for the molten pig. Steel-making efficiency improved considerably and the national average of heat consumption was approximately 1,100,000 kilo-calories per ton of steel, including an exceptionally good cose of 800,000 kilo-calories. Oxygen process was being more applied. Regarding the converter prccess, even plants having no converter started to install experimental top-blowing oxygen converters in order to study the oxygen process.

In the field of electric steel making process, Daido Steel Works, Ltd. and some others constructed the Lectromelt type electric arc furnaces and obtained good results in the reduction of heating duration and material consumption of electric power per unit. The rolling (operation) field was most emphasized in the equipment-modernization program and as stated above, new constructions were completed during 1954, most of which now started operation. This improved both yield and quality and decreased heat consumption. Because of the improvement in quality, the use of sheets became much wider and the production of hot-rolled silicon steel sheets in strip gave the consumers much benefit on account of its better yield. As demands for high tensile steel much increased, the techniques for its production advanced and also the quality of welding rods used for high tensile steel greatly improved.

During this year, various study groups were reorganized in order to establish the "Society for Joint Study of Iron \& Steel Making Technique" with the object of promoting technical studies by the cooperation of the Government, academic and business circles concerned. This Society consists of iron making, steel making, steel products, special steel, quality control and heat economy departments. Each department was organized to enable it to make technical studies on current problems under its jurisdiction.

As explained above, 1954 was the year in which the Japanese iron and steel industry showed a remarkable progress in its technique by reaping the hard-won benefits of the efforts in the preceding years and at the same time laid the foundation for future development. 